\title{
Feasible Time for Extraction of Lead from Spent Paste by Pyrometallurgical Process
}

\author{
Fakhri H. Ibraheem \\ Department of Chemical Engineering, Faculty of Engineering, Koya University, Kurdistan Region - F.R. Iraq
}

\begin{abstract}
This paper focuses on determining the feasible time for production of lead from spent paste (SP) by pyrometallurgical process through the rotary furnace. The extraction process faces several problems due to difficulties to control reaction media conditions. The experiments had been done on rotary furnace which exists in a secondary lead smelter in Baghdad - Khan Dhary. The SP mainly consists of lead sulfate and lead oxides. The experiments are implemented at high temperatures $\left(1300^{\circ} \mathrm{C}\right)$ for reduction and desulfurization. 20 experiments were designed to determine the feasible smelting cycle time. The weight of slag, matte, and lead bullion was determined in each experiment as well as the percent of lead in each phase. These data were analyzed and graphically represented. The reaction's rate profile can be detailed in the following manner: (1) High rate during the first 90 smelting min. Low rate from 90 to $120 \mathrm{~min}$. Very low rate after $120 \mathrm{~min}$. (2) The feasible extraction time is between 120 and 130 min with average lead percent in slag not $>8 \%$. (3) The slag with lead percent higher than $5 \%$ is returned to the furnace whereas the lower one is extracted by the blast furnace.
\end{abstract}

Index Terms — Lead, Pyrometallurgical Process, Secondary Lead Smelter, Spent Past.

\section{INTRODUCTION}

The recycling of lead from lead acid battery scrap (BS) is important for two reasons, the first one is to provide a source for lead metal, and the second is to clean the environment from poisonous materials (Alessandra et al., 2009 and Vest, 2002). The lead in battery consists of alloys for poles and connectors, and pure for positive and negative active materials as shown in Fig. 1 (Vest, 2002 and Wei Zhanga et al., 2016); therefore, the spent paste (SP) is an important source for pure lead (Paul, 2015 and Hota, 2013).

There are three methods to extract lead and as follows:

a. Hydrometallurgical process (Habashi, 1997 and Hotea, 2013).

b. Electrochemical cell (Cole, 1984).

ARO-The Scientific Journal of Koya University Volume VI, No.2 (2018), Article ID: ARO.10375, 6 pages DOI: 10.14500/aro.10375

Received 29 January 2018; Accepted 23 November 2018

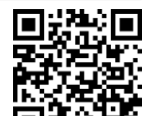

Regular research paper: Published 28 December 2018

Corresponding author's e-mail: fakhri.ibraheem@koyauniversity.org Copyright (C) 2018 Fakhri H. Ibraheem. This is an open-access article distributed under the Creative Commons Attribution License.
"The objective of the hydrometallurgical methods, or electrolytic methods, is to electrically and selectively reduce all lead compounds to metallic lead" (Vest, 2002).

c. Pyrometallurgical process by the blast and/or rotary furnace (EPA, 1986; Habashi, 1997; and Hota, 2013).

The production technology starts by breaking the BS and separating its components of plastics, polyvinyl chloride, lead metals, and SP (Errington, 2005; Vest, 2002; and Wei Zhanga et al., 2016). The SP represents about 56\% weight percent of total battery weight. It consists of about $20 \%$ lead oxides $\mathrm{PbO}_{x}$ and $80 \%$ of lead sulfate $\mathrm{PbSO}_{4}$ (Paul, 2015; Jaeck, 1989; United Nation, 2002; and Wei Zhanga et al., 2016). The SP is charged into a rotary furnace which is shown in Fig. 2 (Monometer Co., Ltd., manual).

A reduction reaction occurs to lead oxides during the $1^{\text {st }} \mathrm{h}$ of smelting by coke (anthracite). A desulfurization reaction occurs to lead sulfates during the $2^{\text {nd }} \mathrm{h}$ (Wright et al., 1994; Kateřina et al., 2015). Fluxing agents are mixed with the charge to improve extraction reaction media. They consist of sodium carbonate $\left(\mathrm{Na}_{2} \mathrm{CO}_{3}\right)$ to create molten reaction media, coke for reduction reactions of lead oxides, salt $\mathrm{NaCl}$ to reduce slag molten temperature, and iron filings for desulfurization reaction of lead sulfate (Habashi, 1997; Iain et al, 2001; Tuffrey, 1989; and Yliaho, 2016).

The chemical reactions inside the furnace during the $1^{\text {st }} \mathrm{h}$ are determined as follows (Arnout et al, 2011; Benrontol, 2010; United Nation, 2002; Vest, 2002; and Yliaho, 2016).

$$
\begin{aligned}
& \mathrm{PbO}+\mathrm{CO} \underline{800^{\circ} \mathrm{C}} \mathrm{Pb}+\mathrm{CO}_{2} \\
& \mathrm{PbO}_{2}+\mathrm{C} \underline{800^{\circ} \mathrm{C}} \mathrm{PbO}+\mathrm{CO}
\end{aligned}
$$

$$
\mathrm{PbSO}_{4} \underline{1000^{\circ} \mathrm{C}} \mathrm{PbO}+\mathrm{SO}_{3}
$$

$$
\mathrm{SO}_{3} \rightarrow \mathrm{SO}_{2}+1 / 2 \mathrm{O}_{2}
$$

Whereas the chemical reactions through the $2^{\text {nd }} \mathrm{h}$ are as follows:

$$
\begin{gathered}
\mathrm{PbSO}_{4}+4 \mathrm{C} \underline{1000^{\circ} \mathrm{C}} \mathrm{PbS}+4 \mathrm{CO} \\
\mathrm{PbSO}_{4}+2 \mathrm{C} \geq 1000^{\circ} \mathrm{C} \\
\mathrm{PbS}+2 \mathrm{CO}_{2}
\end{gathered}
$$




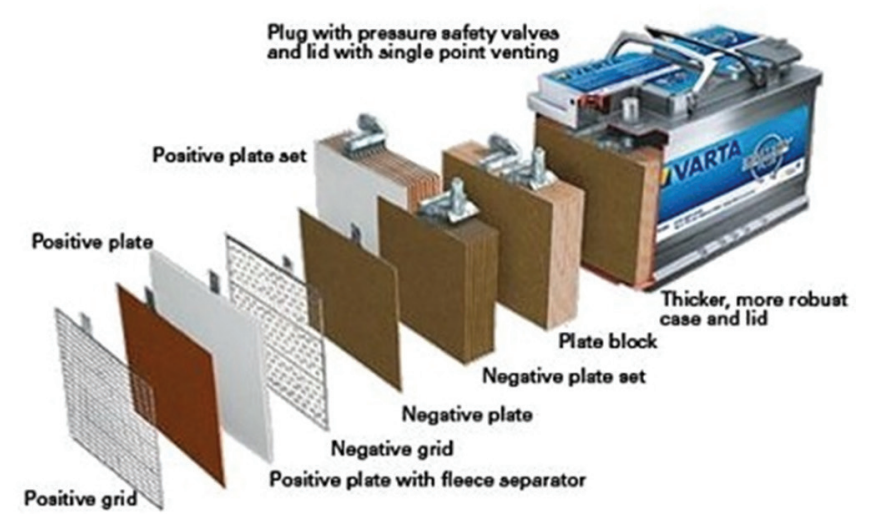

Fig. 1. Lead acid battery components.

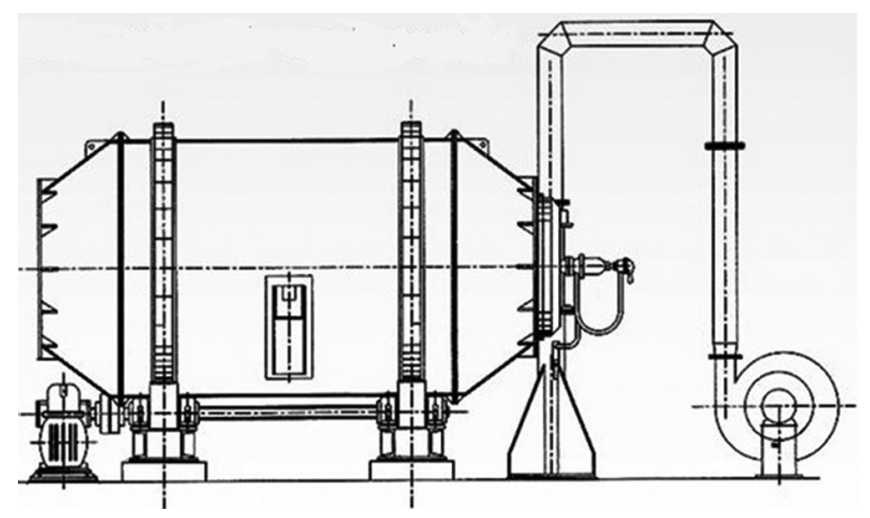

Fig. 2. Rotary furnace with burning system.

$$
\begin{aligned}
& \mathrm{PbS}+\mathrm{PbO} \geq 1000^{\circ} \mathrm{C} \mathrm{Pb}+\mathrm{SO}_{2} \\
& \mathrm{PbS}+\mathrm{Na}_{2} \mathrm{CO}_{3} \underline{1200^{\circ} \mathrm{C}} \mathrm{Na}_{2} \mathrm{~S}+\mathrm{PbO}+\mathrm{CO}_{2} \\
& \mathrm{PbS}+\mathrm{Fe} \underline{1200^{\circ} \mathrm{C}} \mathrm{FeS}+\mathrm{Pb}
\end{aligned}
$$

It is shown that there are many reactions. The rate of these reactions depends on efficient mixing, heat distribution, and concentration of reactant materials (USAID/Egypt, 1999).

The molten metal, slag, and additives are poured into $500 \mathrm{~kg}$ cast iron pots after specified smelting time as shown in Figs. 3-5.

Physically, the molten media are recognized to three layers before pouring. The lower layer is the lead which is of higher density, the matt which is the transition zone between the metal and slag, whereas the slag is the upper layer as shown in Fig. 6 (Calvo, 1985 and Wei Zhanga et al., 2016).

The production is crude lead bullions. The red shiny color for slag is recognized easily; therefore, it is poured in separated pots. The matt is flowing with the lead and forms an upper layer over the crude lead pot. The matt is removed manually and returned to the furnace. Fig. 7 shows two pots one with the matt layer and the other after removing it. The polluted gases are exhausted of the furnace through a cooling and filtration system (Hawkins, 1993 and Jitka, 2016).

A safety precaution was taken in consideration. Monthly monitoring of lead in blood is done by the medical department.

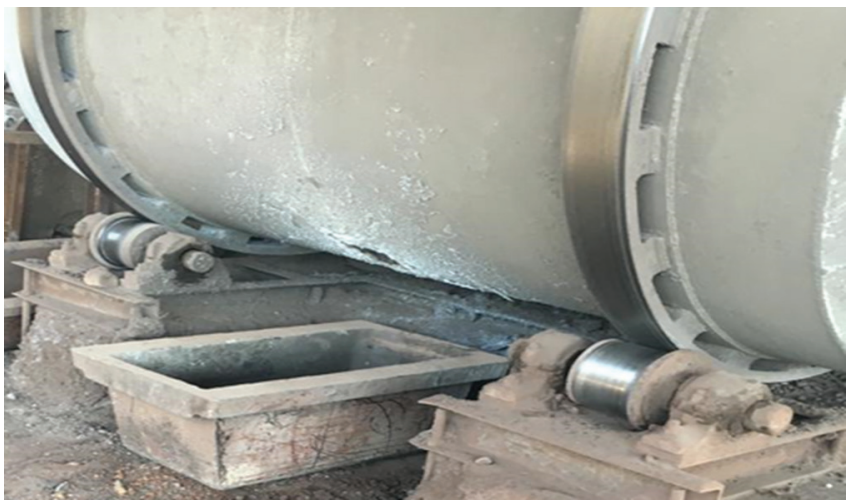

Fig. 3. The actual rotary furnace where the experiments had been done.

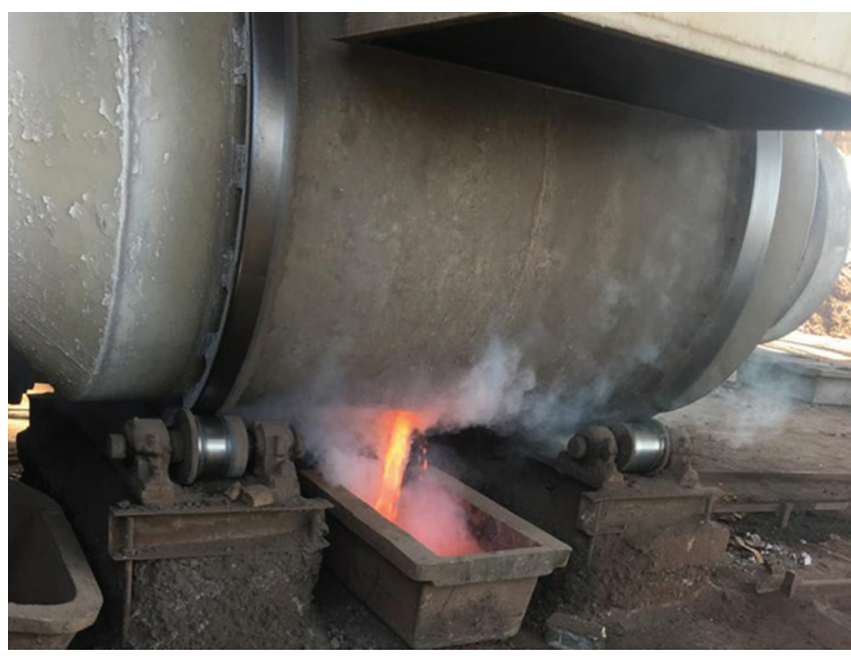

Fig. 4. Pouring of molten metals, slag, and additives.

The research experiments were done on rotary furnace in secondary lead smelter factory in Baghdad - Khan Dhary. The aim of this paper is to search for the feasible lead extraction time from SP.

\section{EXPERIMENT EQUIPMENT}

a. Rotary furnace: A 1.5-m diameter, $2 \mathrm{~m}$ long rotary furnace is manufactured by Monometer Co., Ltd., UK. Its' capacity is 1 ton charge weight without additives. The furnace is equipped with $70 \mathrm{~L} / \mathrm{h}$ gasoil burner. A geared motor rotating drive unit is assembled with the furnace; therefore, it rotates at a constant speed of $2 \mathrm{rpm}$ (Vest, 2002).

b. Cooling and filtration system for polluted gases (Calvo, 1985).

\section{Methodology}

\section{A. Design of Experiments}

The efficiency of extraction is affected by many factors in addition to the smelting time such as temperature, mixing rate, and amount of fluxing agent. The weight of the charge is fixed at 1 ton SP. The amount of fluxing agents is determined from the lead smelting knowhow by Chloride Com. Ltd., 


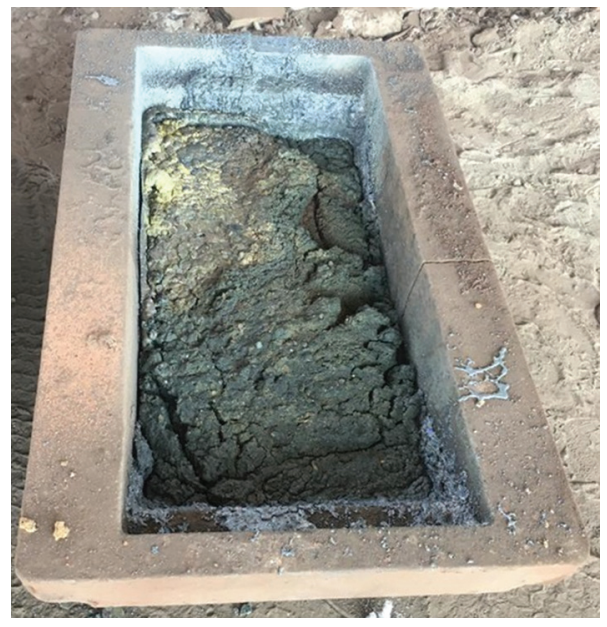

Fig. 5. Cast iron pot, capacity $500 \mathrm{~kg}$.

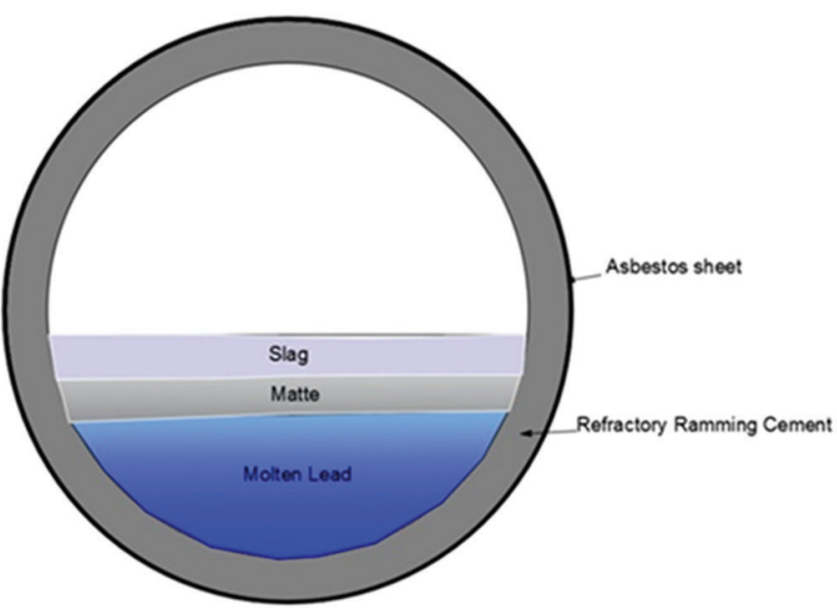

Fig. 6. The molten layers inside the rotary furnace.

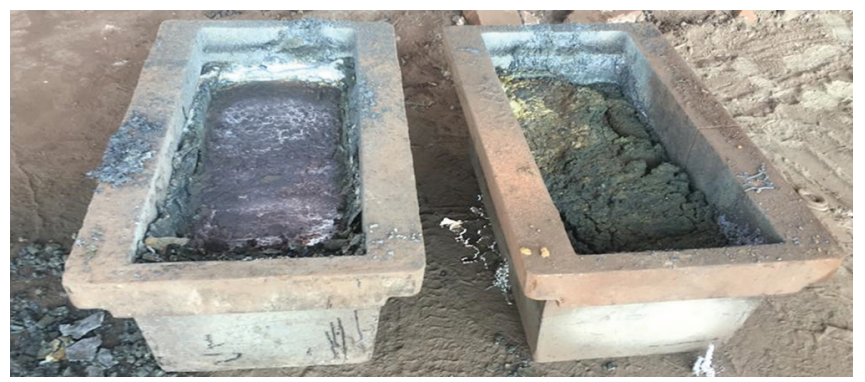

Fig. 7. Two metal pouring cases, the right one with matt and the other without.

UK, manual. The charge type of SP is taken in consideration as shown in Table I (Paul, 2015 and Errington et al, 2005 and Eric, 1989).

The smelting time is considered as a variable parameter. The production data after the $1^{\text {st }} \mathrm{h}$ is determined each 5-10 min. For this research, 20 experiments have been conducted to cover the range from 60 to $160 \mathrm{~min}$. The weight of lead bullion, matt, and slag was determined for each run. The amount of remaining lead in the slag is determined for each run, and is considered as a guide for efficient extraction.
TABLE I

Amount of Fluxing Agents For One-Ton Charge

\begin{tabular}{lc}
\hline \hline Material & Amount in $\mathrm{kg}$ \\
\hline Sodium carbonate $\mathrm{Na}_{2} \mathrm{CO}_{3}$ & 80 \\
Coke as anthracite & 60 \\
Iron filings & 50 \\
Commercial salt $\mathrm{NaCl}$ & 25 \\
\hline
\end{tabular}

\section{B. Chemical Analysis}

The amount of the remaining lead in slag is determined by chemical analysis method according to the chemical analysis procedure manual-CHLORIDE technical documents (Dean, 1979). The results were confirmed by additional X-ray florescence equipment manufactured by Swiss ARL company, model 1988.

\section{Temperature Measurement}

A $300 \mathrm{~mm}$ portable manual thermometer type $\mathrm{k}$ from "Thermo Co., Ltd.," was used. The temperature of the exhaust gases was measured through the gap between furnace and exhaust duct. It is calibrated by Iraqi Standardization and Quality Control Organization (ISQCO).

\section{Weighing Scale}

Hanged weighing scale was used with capacity $500 \mathrm{~kg}$ and $2 \mathrm{~kg}$ accuracy. It is calibrated by ISQCO.

\section{EXPERIMENTAL ReSULtS}

To determine the feasible production technology time, 20 experiments were done for this research whose details are shown in Table II.

\section{Discussion of Results}

1. Increasing the extraction time will increase the amount of produced bullion lead as shown in Fig. 8. The rate of productivity has a uniform increase through $2 \mathrm{~h}$; then, it became slow and approximately constant. The maximum productivity of bullion lead is $400 \mathrm{~kg}$ from 1 ton charge.

2. The weight of matte layer reduces by increasing extraction time (Tuffrey, 1989) which means better separation phases. The matte weight decreases over $2 \mathrm{~h}$. A natural cooling leads to mild separation. Fig. 9 shows the profile of reducing matte weight with time.

3. The percent of lead in the matter is reduced by increasing extraction time. The experiments show that the minimum lead weight percent in matte is $15 \%$. The matte materials are recharged to the rotary furnace for efficient extraction. Fig. 10 shows the rate of lead percent decrease in matte material over a time.

4. The weight of slag is reduced by increasing extraction time. The slag constituent of non-extracted lead metal which is still as sulfate and dioxide, and molten fluxing agents. Fig. 11 shows the rate of slag weight decrease over a time.

5. The weight percent of lead in slag is reduced by increasing extraction time. The rate of decrease is high at the first $2 \mathrm{~h}$. The 
TABLE II

Details of Experimental Data

\begin{tabular}{|c|c|c|c|c|c|c|}
\hline Experimental No & $\begin{array}{l}\text { Extraction time } \\
\text { minutes }\end{array}$ & $\begin{array}{l}\text { Weight of } \\
\text { slag kg }\end{array}$ & $\begin{array}{l}\text { Percentage lead } \\
\text { in slag }\end{array}$ & $\begin{array}{l}\text { Weight matte } \\
\text { zone } \mathrm{kg}\end{array}$ & $\begin{array}{l}\text { Percentage lead in matte } \\
\text { zone }\end{array}$ & $\begin{array}{l}\text { Weight of bullion } \\
\text { lead } \mathrm{kg}\end{array}$ \\
\hline 1 & 60 & 120 & 37 & 28 & 30 & 210 \\
\hline 2 & 61 & 122 & 35 & 30 & 28 & 200 \\
\hline 4 & 70 & 115 & 30 & 35 & 27 & 205 \\
\hline 5 & 80 & 117 & 24 & 32 & 32 & 250 \\
\hline 6 & 80 & 112 & 25 & 30 & 30 & 240 \\
\hline 9 & 100 & 93 & 16 & 25 & 21 & 338 \\
\hline 10 & 100 & 90 & 17 & 27 & 22 & 330 \\
\hline 11 & 110 & 86 & 12 & 24 & 20 & 364 \\
\hline 12 & 114 & 80 & 13 & 20 & 20 & 350 \\
\hline 13 & 120 & 81 & 12 & 24 & 18 & 382 \\
\hline 18 & 142 & 65 & 11 & 16 & 18 & 400 \\
\hline 19 & 150 & 70 & 8 & 18 & 14 & 414 \\
\hline 20 & 160 & 68 & 10 & 18 & 15 & 405 \\
\hline
\end{tabular}

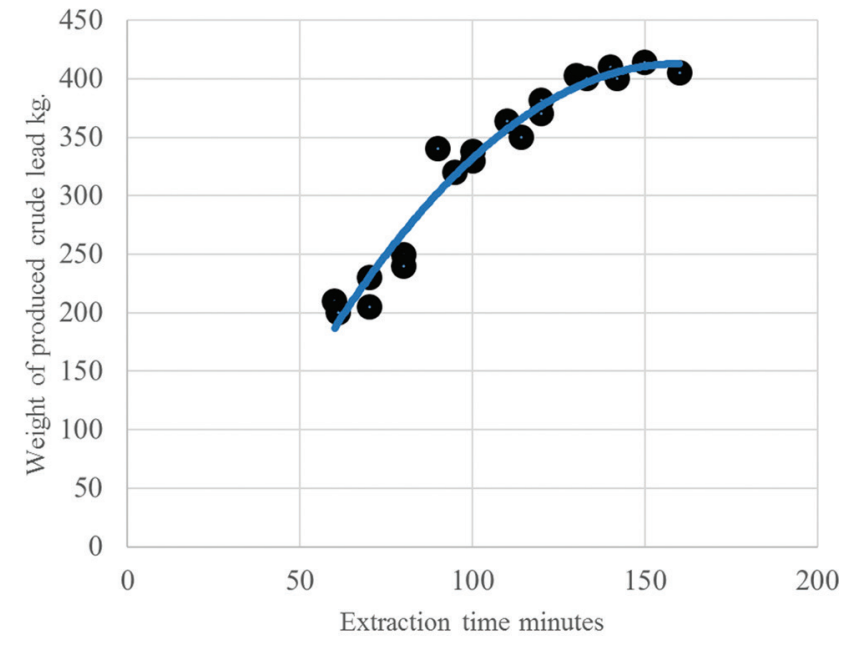

Fig. 8. The effect of extraction time on net lead bullion production efficiency.

lowest lead percent in slag is $8 \%$. The slag that contains lead $>5 \%$ weight percent is returned to the furnace. The accumulated slag with lead percent $<5 \%$ is transferred to blast furnace unit for more extraction. The physical properties of slag are effected by its' composition. It is shown obviously that the density of slag is reduced with time while its' viscosity increases. Fig. 12 shows the profile of lead extraction efficiency.

6. Fig. 12 shows a decrease in extraction efficiency $>2 \mathrm{~h}$ smelting. During the period from 120 to $160 \mathrm{~min}$, the saving in the lead is only $2 \%$, that is, $20 \mathrm{~kg}$. The global price of lead in December 2017 is 1140 US\$ for one pure metric ton (Mining Market and Investment sheet). The value of $20 \mathrm{~kg}$ lead is 23 US\$. During the $40 \mathrm{~min}$, the amount of consumed diesel oil is $47 \mathrm{~L}$. The local market price of 1-L is 0.4 US\$. The value of fuel is 19 US\$ and when adding the costs of

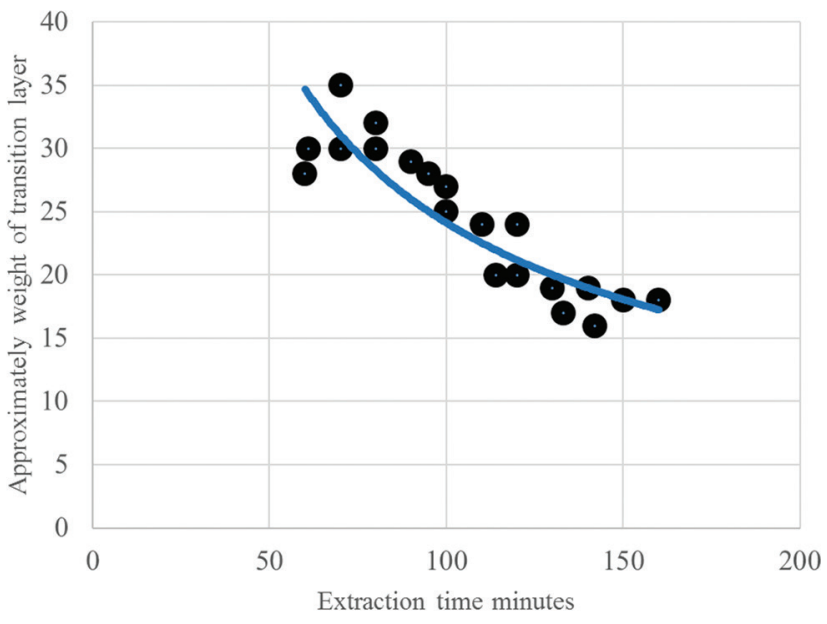

Fig. 9: The effect of extraction time on the matte weight.

operation and services, it looks that the production cost is higher than the saving amount of lead. It is shown obviously that increasing the extraction time $>130 \mathrm{~min}$ is not feasible.

\section{Conclusions}

1. The productivity efficiency of crude lead improved by increasing extraction time.

2. The feasible extraction time is between 120 and $130 \mathrm{~min}$.

3. The best amount of crude lead produced from 1 ton SP charge is $400 \mathrm{~kg}$.

4. The weight percent of lead in slag is about $8 \%$ after $2 \mathrm{~h}$ smelting.

5. The slag with percent lead $>5 \%$ is returned to the furnace with new charge. 


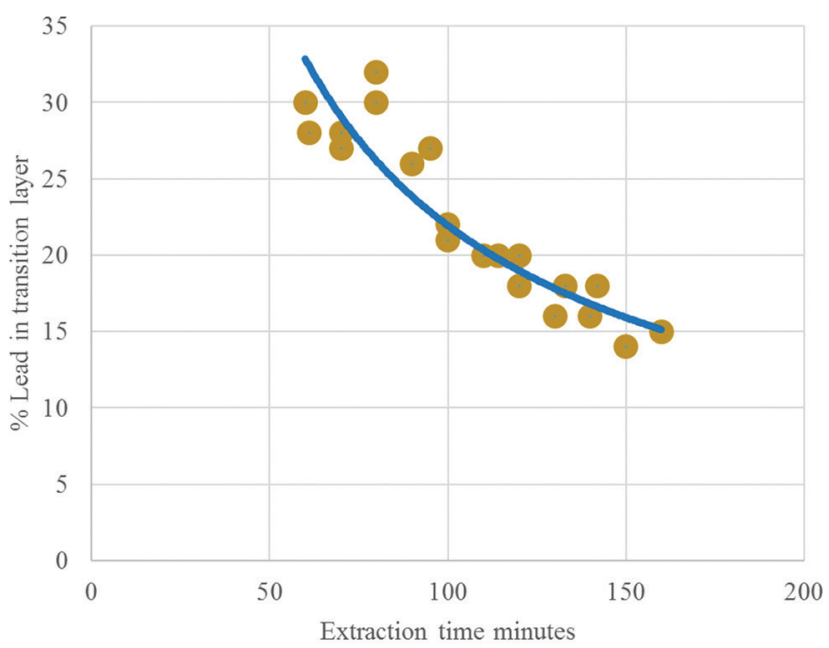

Fig. 10. The effect of extraction time on the matte materials lead percent.

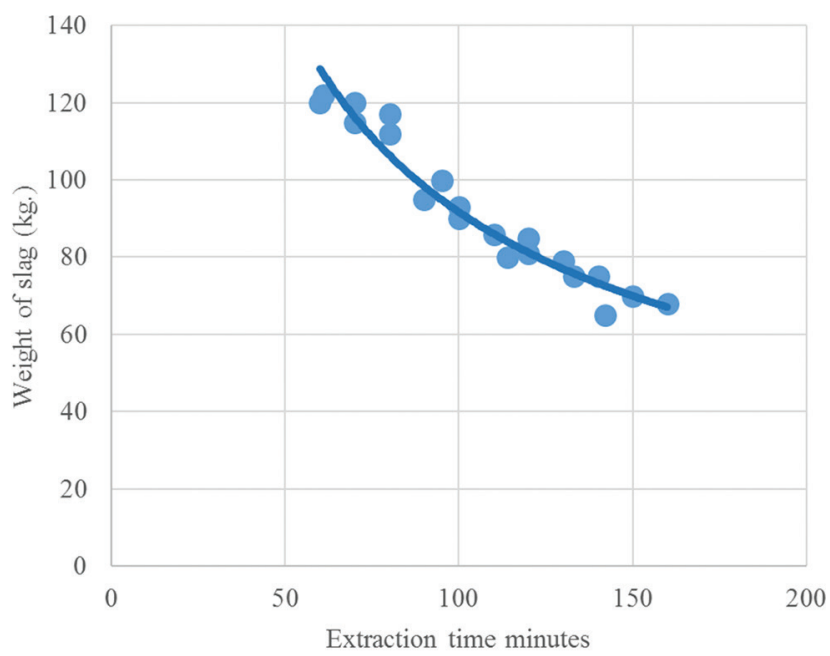

Fig. 11. The effect of extraction time on the amount of produced slag.

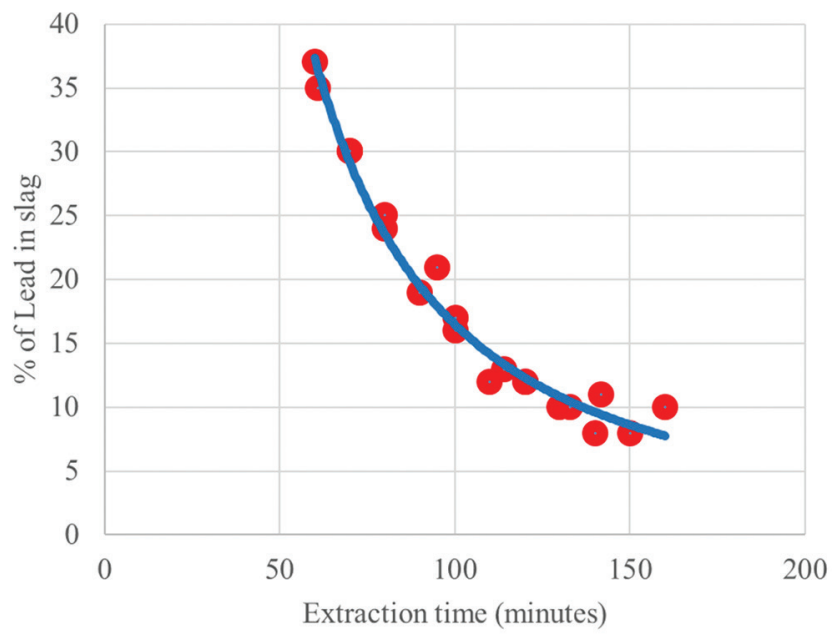

Fig. 12: The effect of extraction time on percent of lead in slag.

\section{RECOMMENDATIONS}

The following points are recommended for future work:

1. The mixing efficiency effect on extraction rate.

2. The effect of fluxing agent constituents' amount on the extraction efficiency.

3. The effect of extraction temperature on production efficiency.

\section{REFERENCES}

Alessandra, S., Antunes, A., Filho, I.N., Venquiaruto, L.D., de Oliveira, D., Mossi, A., Di Luccio, M., Treichel, H., and Dallago, R., 2009. Qualitative lead extraction from recycled lead-acid batteries slag. Journal of Hazardous Materials, 172, pp.1677-1680.

Arnout1, D.S., 2011. Thermodynamics of Lead Recycling. Metallurgy Conference, Belgium, p.10.

Benrontol., 2010. Primary Metal Production No. 20051786. Available from: https://www.scribd.com/document/39618162/CM2200-Primary-Metals.

Bill, E.P., Arthur, P., Wang, J., Dong, Y., 2005. ISA-YMG Lead Smelting Process. Proceeding of the International Symposium on Lead and Zinc Processing, Kyoto, Japan.

Brew, R.B.M., Fountain, C., Pritchard, J., 1991. ISASMELt for secondarly lead smelting. s.1. 10 $0^{\text {th }}$ International Lead Conference, United Kingdom, pp.171-180.

Calvo, F.A., 1985. Metal losses in lead blast furnace slag: The influence of the charge and the reducing conditions. Canadian Metallurgical Quarterly, Spain, pp.345-348.

Chemonics International, I., 1999. Technical and Economic Study for Smalland Medium-Sized Lead Smelters. Available from: http://www.pdf.usaid.gov/ pdf_docs/Pnacy063.pdf.

Cole, E.R., Lee, A.Y., Paulson, D.L., 1984. Electrolytic method for recovery of lead from scrap batteries. United States Department of the Interior, USA.

Dean, J.A., 1979. Lange's Handbook of Chemistry. $12^{\text {th }}$ ed. McGraw-Hill, New York.

EPA, 1986. Secondary Lead Processing. U.S. Environmental Protection Agency, Research Triangle Park, USA.

Eric, R., 1989. Thermodynamic analysis of the direct converting of lead sulphide. Journal of the South African Institute of Mining and Metallurgy, 89, pp.33-39.

Habashi, F., 1997. Handbook of Extractive Metallurgy. WILEY-VCH, Canada.

Hawkins, K.R.P., 1993. Lead/acid battery recycling and the new isasmelt process. Journal of Power Sources, 42, pp. 299-313.

Hotea, V., 2013. Clean technology of lead recovery. Applied Economics and Management, 2, pp.263-269.

Iain, T., Ric, M., Smith, GN., 2001. LEAD the Facts. Surrey KT12 4RG. Ian Allan Printing Ltd., Hersham, London UK.

Jaeck, M.L., 1989. Primary and Secondary Lead Processing. Elsevier B.V. All Rights Reserved, Canada, pp.113-118.

Jahahshahi, S., Sun, S., 1992. Studies on the reduction kineticsof metalurgical lead slags. $4^{\text {th }}$ International Symposium on Metallurgical Slags and Fluxes, Tokyo.

Jitka, M., 2016. Recycling of Non-Ferrous Metals. VŠB Technical University of Ostrava, Czech Republic.

Kateřina, S., Manoko, L.M.K., 2015. Theory of Production of Non-Ferrous Metals and Alloys. VŠB Technical University of Ostrava, Moravian-Silesian Region, Czech Republic.

Queneau, P.B., Leiby, R., Robinson, R., 2015. Recycling lead and zinc in the United States. World of Metullargy, 3, pp.149-163. 
Rabah, M.A., Barakat, M., 2001. Energy saving and pollution control for short rotary furnace in secondary lead smelters. Renewable Energy, 23, pp.561-577.

Seetharaman, S., 2005. Fundamentals of metallurgy. Woodhead Publishing Limited, England.

Tuffrey, N.E., 1989. Pyrometery studies of the combustion of lead concentrate particles under controlled conditions. Ph D Thieses, University of British Colombia, Canada.

United Nations, T.W.G., 2002. Preparation of the Technical Guidelines for the Environmentally Sound Management of Waste Lead-Acid Batteries. United Nations Environment Programme, Geneva.

Vest, D.I.H., 2002. Fundamentals of the Recycling of Lead Acid Batteries. Available from: https://www.energypedia.info/images/7/78/Fundamentals_of the_Recycling_of_Lead-Acid_Batteries.pdf.

Wright, S., Jahanshahi, S., Errington, W.J., 1994. Reduction kinatics of slags produced from recycling of lead batteries; pyrometallurgy for complex materials and wastes. The Minerals, Metals and Materials Society, 5, pp.121-132.
Wright, S., Lim, H., Rand, J., 1994. An Investigation of the Reduction of Battery Paste (Al2O3-As2O3-CaO-FeO-Fe2O3-PbO-Sb2O3-SiO2) Slags with Graphite. The Minerals, Metals and Materials Society, Warrendale, PA, pp. 11-22.

Yliaho, S., 2016. Distribution of Gallium, Germanium, Indium and Tin between Lead Bullion and Slag. School of Chemical Technology Master's Thesis for the Degree of Master of Science in Technology. Alato University, Espoo.

Zhang, C., Zahler, R.Z., 2009. Current Status and Outlook on Chinese Secondary lead Industry. International Secondary Lead Conference, Macau.

Zhanga, W., Yang, J., Wu, X., Hu, Y., and Yu, W., 2016. A critical review on secondary lead recycling technology and its prospect. Renewable and Sustainable Energy Reviews, 61, pp.108-122.

Zhi, S., Cao, H., Lin, X., Zhang, X., 2017. Spent lead-acid battery recycling in China a review and sustainable analyses on mass flow of lead. Waste Management, 64, pp.190-201. 